\title{
Proposed Changes to Coors Porcelain Co. Recipe for Fueled Reactor Tubes (Memo to Mr. Bob L. Mornin)
}

\author{
T. C. Merkle
}

DEC 30090

OSTI

NSTHEDHON OF THIS DOOMCNT IS UNLMIED P

July 27, 1961
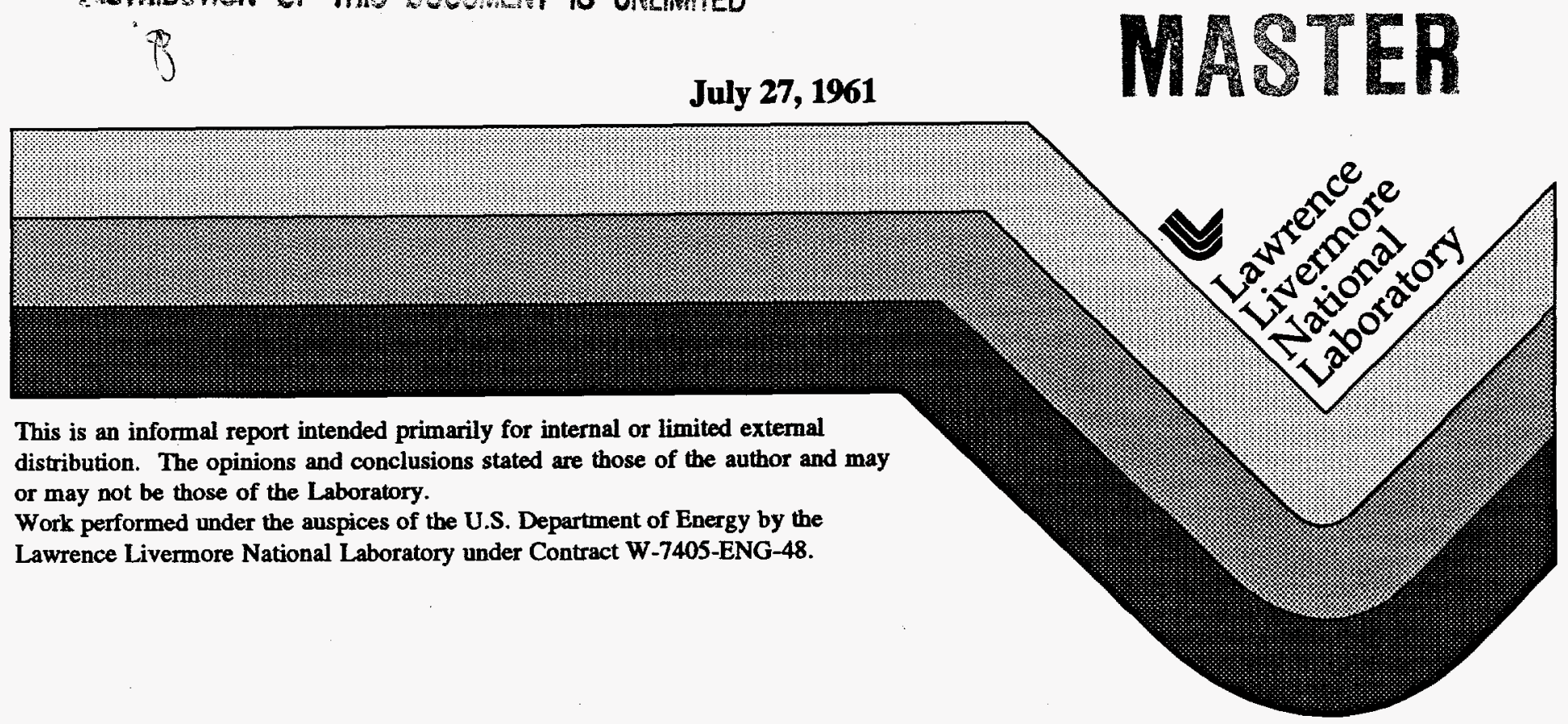


\section{DISCLAIMER}

This report was prepared as an account of work sponsored by an agency of the United States Government. Neither the United States Government nor any agency thereof, nor any of their employees, make any warranty, express or implied, or assumes any legal liability or responsibility for the accuracy, completeness, or usefulness of any information, apparatus, product, or process disclosed, or represents that its use would not infringe privately owned rights. Reference herein to any specific commercial product, process, or service by trade name, trademark, manufacturer, or otherwise does not necessarily constitute or imply its endorsement, recommendation, or favoring by the United States Government or any agency thereof. The views and opinions of authors expressed herein do not necessarily state or reflect those of the United States Government or any agency thereof. 


\section{DISCLAIMER}

Portions of this document may be illegible in electronic image products. Images are produced from the best available original document. 
Nr. Bob. I. Mornin

Project Kanager

Coosulareelain Company

Calden, Colorado

Dear Bob:

The following infermation for use with fueled tubes is of a prelininary netire Intended for guidance only. More definitive information will follor as it w: becones available.

Because of various evaluation studies on fuel stability, it is nor proposed that Coors (Subcontract 165) change thelr reaipe for fueled tubes. Spec1fically, zirconyl nitrate should be used in addition to uranyl nitrate. The detalled changes to be made in the contract at this time are listed below.

Section III (COB-985, page 1)

Under 2. Materials

Add:

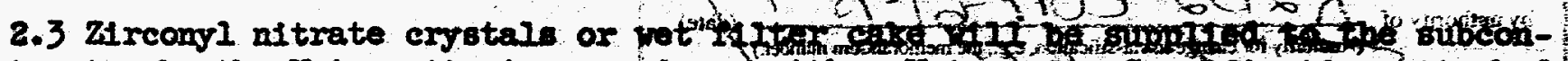

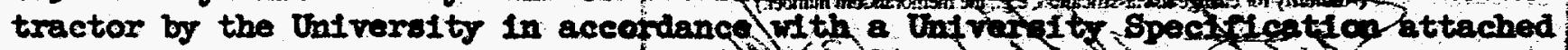
hereto.

hor

Under 3.3 Density of Flementa

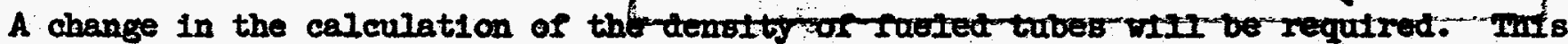
information will be forwanded as the information becomes available.

Add a Section after Section II.

II.A. Zirconyl Nitrate Tantative Speciflcation

This speciflcation is tentative only. Zirconium nitrate will be procured of the highest purity practicable.

Tentative Speciflcation: Zirconyl Hitrate

1. Scope

1.I General: This specification defines the requirements for high purity Zircongl Mitrate prepared by arbitrary processes.

2. Reference Documents

None

\section{Requirements}

3.1 Chemical Composition: Material shall be supplied in the form of a molst highly acid filter cake (ca.35-40\% acid) containing both soluble and insoluble zirconium. This cake contains 25 percent by wt. zirconium.

Crystalline material may be used if it becomes available. 
3

\section{Ides, its verr \\ MOITAOIFIZZA.JDJa

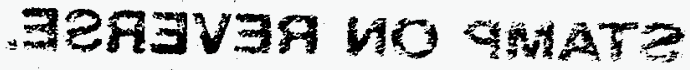

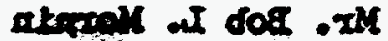
regened tootorg

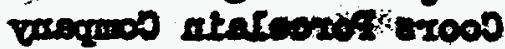
absratos smbios

tdod rova

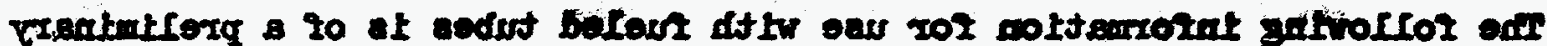

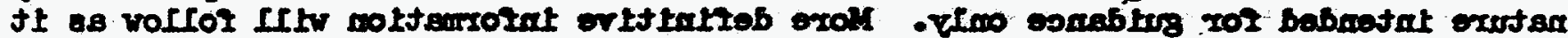

- aldalters aemoosed

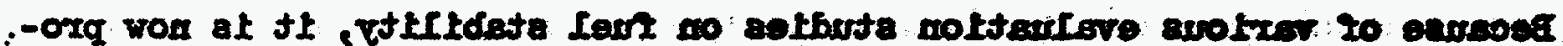

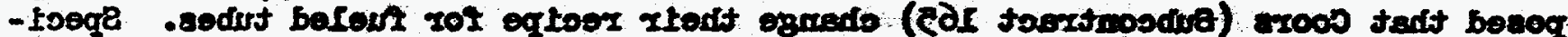

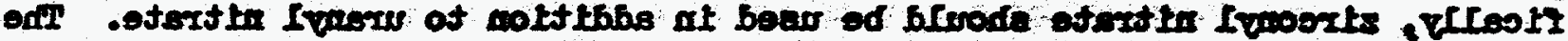

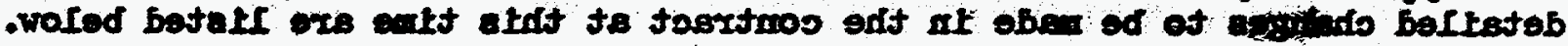

( 1 ogsq $88 e-600$ ) II noltosa

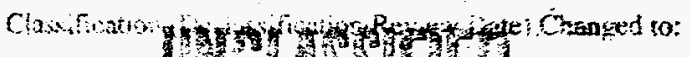

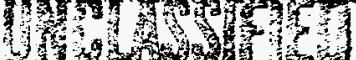

1.

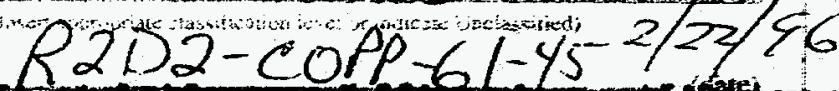

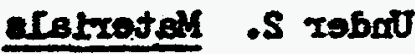

: $\mathbf{6 6 A}$

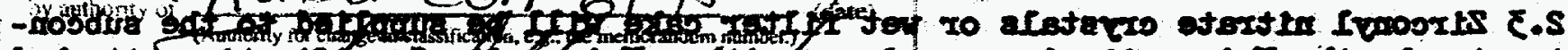

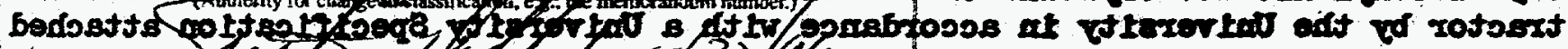
by yerified by

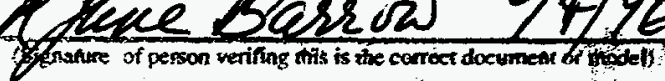

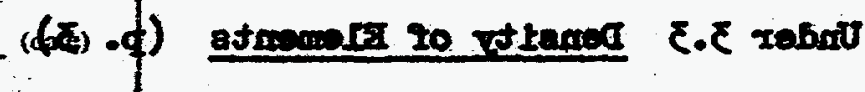

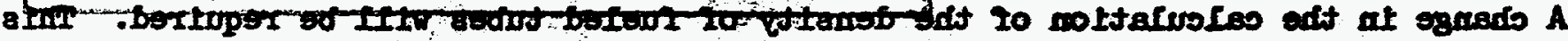

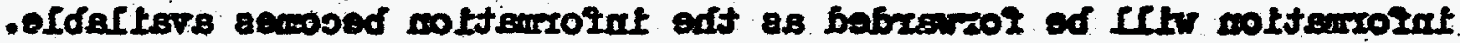

- I mologa rests noltoa 8 G6A

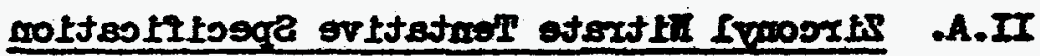

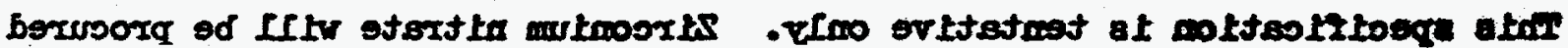

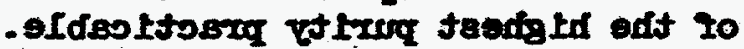

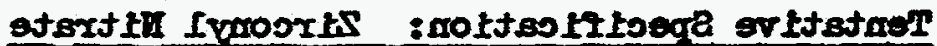
oqood . II

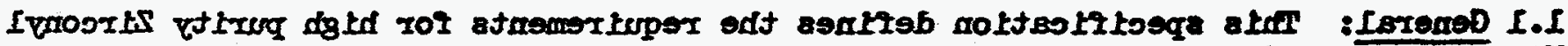

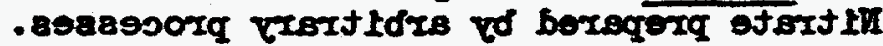
astremrocl someroter .S

emols afmemertuper.$\Sigma$

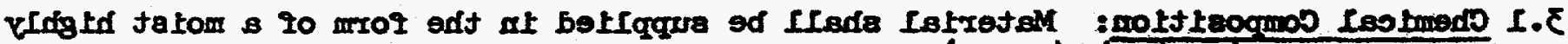

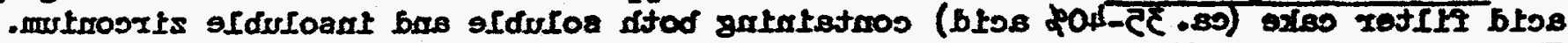

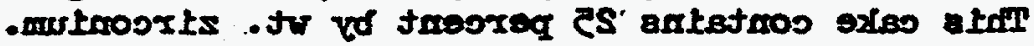




\subsection{Purity}

3.2.1 Impurity Concentrations - Impurities in the samples of the solution shall not exceed the following limits on a dry basis as $\mathrm{ZrO}\left(\mathrm{NO}_{3}\right)_{2}$.

Element

Fluorine

Magnesium

Vanadium

Barium

Copper

Calcium

Chromium

Nicke1.

Tin

Aluminum

Phosphorus

Potassium

Molybdenum

Silicon

Iron

Carbon

Beryllium

Bafnium
Maximu Concentration

Dry Basis, ppm by wt

$3.2 .2 \mathrm{c} / \mathrm{q}$ Summation - The summation of $\mathrm{C} / \mathrm{q}$, where $\mathrm{C}$ is the concentration in $\mathrm{ppm}$ by wt. on a dry basis $\left(a \cdot \mathrm{ZrO}\left(\mathrm{HO}_{3}\right)_{2}\right)$ and $\mathrm{q}$ is the tabulated value, shall not
exceed 50 for any sample.

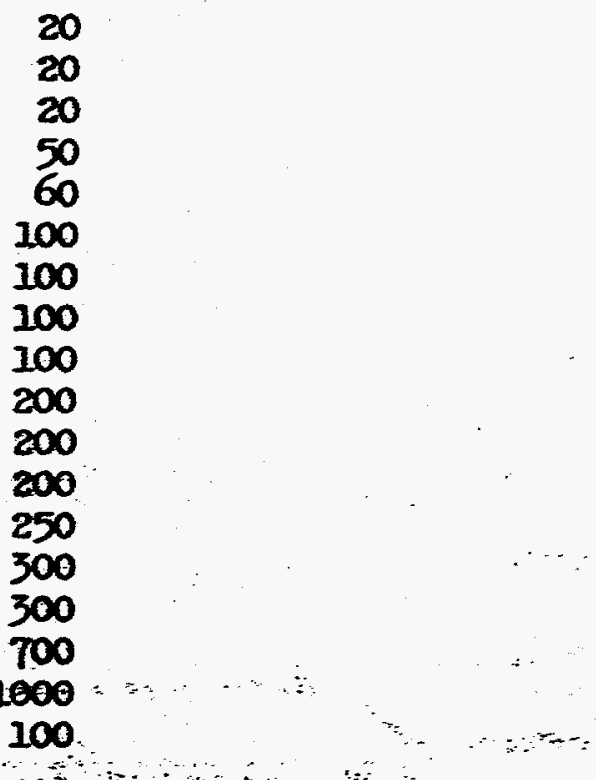

Element

\section{Gadolinium}

Boron

Hafuium

Semarium

Cadmium

Europium

Cobalt

If thium

Indium

Manganese

Cold

Rhodium

Sodium

Ititantiun

S1lver

9
1
4
30
5
6
8
12
20
20
25
30
40
50
50
50

3.2.3 Other Impurities - No elements other then Uraniva, Oxygen, Nitrogen, Zirconium and Hyrosen and those 1 isted in paragraphs 3.2 .1 and 3.2 .2 shail be individually present in the finished fliter cake to an extent creater than 100 ppa by wt. on a ary $\operatorname{Rro}\left(\mathrm{m}_{3}\right)_{2}$ basis. 


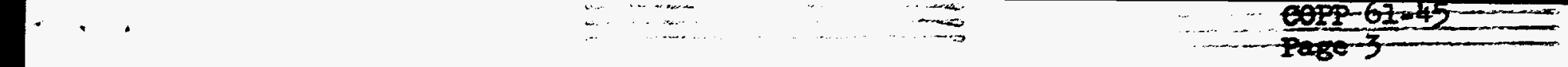

Changes in Process Specifications (VI.), cOB-987

The incorporation of $\mathrm{ZrO}_{2}$ in Tory IIC fuel elements can be covered by the following changes in Addendum No. 1 of Appendix A to Subcontract 165 betreen the University and Coors. (Document No. COB-987, Revision I):

VI. Process Specification

Introduction (p. 1)

Insert a new b) "adding zirconyl nitrate solution to the slurry".

Change b) to c) and add the phrase "and zirconium".

c) will be d) when relettered should read "filtering drying and calcining the solids."

Change subsequent letters to conform i.e. c) to d) etc.

Rav Material (p. 1)

Insert subheading "BeO powder" followed by existing paragraph.

Insert subheading "zircogyl Hitrate" and the following paragraphs.

"Reactor grade airconyl nitrate shajl be dissolved in a $0.5 \mathrm{H}$ nitric acid solution to a concentration of about $0.05 \mathrm{~g} . \mathrm{ZrO}$, per ml. The solution should be filtered prior to use to remove insoluble materials and analyzed for $\mathrm{ZrO}_{2}$ content. Analysis shall consist of arying and ioniting an ellquot of the solution at $1500^{\circ} \mathrm{F}$ for 3 hours.

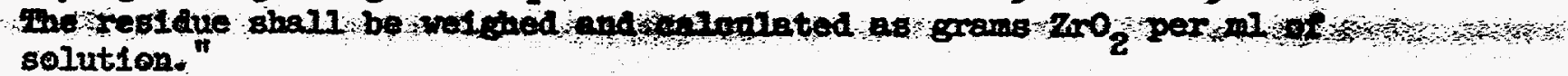

"There is some question as to the stability of these zirconyl nitrate colutions. They tend to hydrolyze and precipitate on standing even with the nitric acid present. It is therefore necessary that the solution be made up and the concentration determined just prior to use. A test is underway to determine to what extent the solution is unstable. The results of this test will be forwarded in the near future."

Operations (p. 3)

1. Mixing - First paragraph unchanged. Second paragraph revised as follows:

"The BeO slurry shall be moved to the mixing tank and the proper amounts of Oy Hitrate and zirconyl Iitrate colutions added to it with thorough mixing. After sufficient mixing to assure a unfform slurry, Ammonium Hyaroxide solution vill be added to the mixer to preclpptate the Oraliey and Zirconium. The cospletenops of pweclpitation vill be chacked by a pli meter. The fInal pH should be about 9."

Third paragraph unchanted. 
2. Flitering - (p. 3) Flrst paragraph. The next to last sentence should read: "The fliter cake will be washed with the D.I. water, containing about 0.2 percent $\mathrm{MH}_{4} \mathrm{OH}$, used to clean out the $\mathrm{mix}$ tank." The last sentence in the paragraph reads correct.

New 4. Calcining - Should read as follows:

"The dried filter cake shall be calcined at a maximum temperature of $1000^{\circ} \mathrm{F}$ for approximately 10 hours. This may be accomplished by loading a $1 / 2$ $\mathrm{mlx}$ batch $(\mathrm{ca.} 900 \mathrm{~g})$ in a covered stainless steel can ( $4^{\prime \prime} \times 8^{n} \times 6^{n}$ high). The flring be done in a tunnel kiln on a continuous basis, by pushing on the $4 \times 6$ face of the can. The calcined cake from each batch shall then be combined and placed in polyethylene bags and suitable contalners on a safe storage rack until used for the next operation."

5. Pugging - (p. 4) First pairagraph. Delete firgt two sentences. Paragraph should start: "The cake is poured..............."

Second paragraph. Second sentence should read: "Upon completion of mixing a cample vill be taken for quantitative determination of the Oralloy, $\mathrm{zr}$, water and binder content." The remalning portion of the paragraph reads
corfect.

Change subsequent numbers under "Operations" to conform, 1.e. (5) to (6) etc.

\section{Additional}

The $\mathrm{ZrO}_{2}$ to $\mathrm{WO}_{2}$ reight ratio in each fueled tube should be $0.692 / 1.000$. Modiflcation to a $\mathrm{ZrO}_{2} / \mathrm{tO}_{2}$ weight ratio as hish as $1.077 / 1.000$ may be made in the near future.

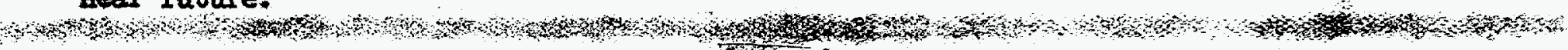

to:

Iours truly,

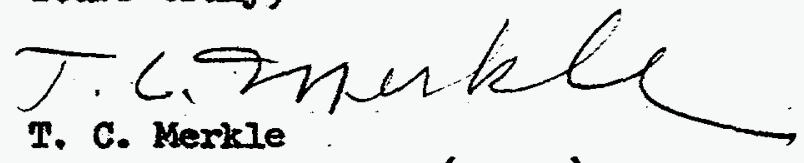

T. C. Merikle

Assoclate Director (Pluto)

TCAS/IE: sd

Distribution:

IA: C. L. Blue

2A: W. Moran

3A: H. Reynolds

4A: T. Merkle

5A: A. Rothman

6A: T. Merkle/File

TA: B. I. Mornin (Coors) 